\title{
Characterization of Calcium and Boron Deficiency and the Effects of Temporal Disruption of Calcium and Boron Supply on Pansy, Petunia, and Gerbera Plugs
}

\author{
Brian A. Krug 1 \\ University of New Hampshire, Cooperative Extension, Spaulding Hall, 38 \\ Academic Way, Durham, NH 03824
}

\author{
Brian E. Whipker \\ Department of Horticultural Science, Box 7609, North Carolina State \\ University, Raleigh, NC 27695-7609
}

Jonathan Frantz

USDA-ARS-ATRU, Mail Stop 604, Toledo, OH 43606

\author{
Ingram McCall \\ Department of Horticultural Science, Box 7609, North Carolina State \\ University, Raleigh, NC 27695-7609
}

Additional index words. Gerbera jamesonii, hydroponics, Hoagland's, Petunia $\times$ hybrida, Viola $\times$ wittrockiana

\begin{abstract}
Pansy (Viola $\times$ wittrockiana Gams.), petunia (Petunia $\times$ hybrida hort. Vilm.), and gerbera daisy (Gerbera jamesonii Bol. ex Adlam.) plants were grown hydroponically to characterize the deficiency symptoms caused by the absence of calcium (Ca) or boron (B). Primary symptoms occurred on the youngest tissue for both elements, but distinct differences between $\mathrm{Ca}$ and $\mathrm{B}$ deficiencies were observed. Plants responding to $\mathrm{Ca}$ deficiency exhibited discoloration and upward rolling of leaves and ultimately necrosis. Plants responding to $B$ deficiency exhibited minor chlorosis, upward curling, and thickening of leaves, distorted meristems, and strap-like leaves. A second experiment investigated how a temporary disruption of $\mathrm{Ca}$ or $\mathrm{B}$ affects the plant throughout the crop cycle. Either Ca or B was removed from the nutrient solution for a 7-day period from Day 15 to Day 21, Day 22 to Day 28, or Day 29 to Day 35 after sowing. After the 7-day disruption, the respective element was reintroduced to the plants. Regardless of when the plants were deprived of $\mathrm{Ca}$ or $\mathrm{B}$, the symptoms of the respective deficiency were present at the end of the experiment. These studies have shown that a temporary disruption of either Ca or B can cause lasting symptoms throughout the plug production cycle. Also, the symptoms that have been observed in plug production were most similar to those symptoms caused by $B$ deficiency, not Ca deficiency.
\end{abstract}

Reports of distorted terminal growth of pansy, petunia, and gerbera plants have become more prevalent, specifically in plugs grown in the high heat and humidity conditions of summer. The problem, considered to be a deficiency of calcium $(\mathrm{Ca})$ or boron (B), could not be confirmed by tissue sam-

Received for publication 26 Feb. 2009. Accepted for publication 18 June 2009.

Thanks to Ball Horticultural Company for plant material, Smithers-Oasis for the root substrates, Scotts for the fertilizer, and the Gloeckner Foundation for grant support.

Use of trade names in this publication does not imply endorsement of products named nor criticism of similar ones not mentioned.

${ }^{1}$ To whom reprint requests should be addressed; e-mail brian.krug@unh.edu. because $\mathrm{B}$ is less available as $\mathrm{pH}$ increases (Marschner, 1995).

Calcium is considered to be the key element in the primary walls of plant cells (Pilbeam and Morely, 2007). As a result of only being mobile in the xylem and dependent on the loss of water through transpiration to take it up, $\mathrm{Ca}$ is classified as an immobile element (Clarkson, 1984). Because of these characteristics of $\mathrm{Ca}$, shoot deficiency symptoms appear primarily on the upper leaves. Visual symptoms include deformed, straplike leaves; chlorosis; and leaves that develop yellow-to-tan margins, eventually becoming necrotic (Nelson, 2003).

Boron is primarily moved from the roots to the shoots passively through xylem (Jones, 1991; Kochian, 1991; Kohl and Oertli, 1961; Raven, 1980). Once in the shoot, B is reported to complex with the cell wall and many of its constituents (Marschner, 1995; Matoh, 1997; Römheld and Marschner, 1991; Taiz and Zeiger, 2002; Thellier et al., 1979). Symptoms of B deficiency typically manifest in the young leaves and, unlike other micronutrient deficiencies, in the roots (Gupta, 1993a). Many of the visible symptoms include aborted growing tips, fast-growing auxiliary shoots, and leaves that are strapped, crinkled, stunted, thickened, and/or upward-cupping. Chlorosis of upper leaves and restricted leaf expansion have also been observed (Jiao et al., 2005; Laffe and Styer, 1989; Mengel and Kirkby, 1987; Stuart, 1991).

Plants with either $\mathrm{Ca}$ or $\mathrm{B}$ deficiencies can produce similar symptoms, leading to confusion. However, Ca-deficient plants will typically develop necrosis earlier in the deficiency syndrome, whereas B-deficient plants do not become necrotic. The initial objective of this study was to characterize $\mathrm{Ca}$ and $\mathrm{B}$ deficiencies in pansies, petunias, and gerbera plugs to improve the process of differentiation of the two deficiencies. The second objective of this study was to determine if a temporary disruption of $\mathrm{Ca}$ or $\mathrm{B}$ availability results in lasting visible deficiency symptoms of that element throughout the crop cycle.

pling. The occurrence and severity of the problem can vary by year, season, stage of plant development, geographical area, and cultivar, especially in pansy.

Calcium and B deficiencies can occur as a result of the lack of the respective element in the growing medium. In greenhouse production, however, it is common practice to use constant liquid feed using a complete fertilizer. Deficiencies of both of these elements can also be induced by drought conditions, reducing the movement of $\mathrm{Ca}$ or $\mathrm{B}$ through the soil solution (Kluge, 1971; Pilbeam and Morely, 2007). Both deficiencies can also be the result of low transpiration rates that limit the movement of $\mathrm{Ca}$ or $\mathrm{B}$ through the xylem (Clarkson, 1984; Jones, 1991; Kochian, 1991; Kohl and Oertli, 1961; Marschner, 1995; Raven, 1980). Plants grown in a high substrate $\mathrm{pH}$ are more susceptible to B deficiency
Expt. 1: Characterizing deficiencies in seedlings. Oasis foam (Smithers-Oasis, Kent, $\mathrm{OH})$ was used as the growing medium. The foam was cut to fit into a $2-\mathrm{mL}$ microcentrifuge tube that had approximately the bottom $3 \mathrm{~mm}$ removed. Before sowing, the growing medium was leached three times with deionized water. 'Dynamite Yellow' pansy, 'White Storm' petunia, and 'Festival Apricot' gerbera were sown, one seed per tube. Once sown, seeds were placed in a germination chamber with a constant temperature of $20^{\circ} \mathrm{C}$. Light was provided by fluorescent bulbs with a photosynthetic photon flux $(P P F)$ of 24 to $75 \mu \mathrm{mol} \cdot \mathrm{m}^{-2} \cdot \mathrm{s}^{-1}$ at the surface of the growing medium for $12 \mathrm{~h}$ per $\mathrm{d}$. Oasis foam was kept moist using deionized
Materials and Methods 
water until seeds germinated. After germination, plant tubes were transferred into $2.3-\mathrm{L}$ plastic containers with holes drilled in the lids to hold the microcentrifuge tubes. Plants were then moved into a greenhouse with day/night temperature set points of 23.9/ $17.8^{\circ} \mathrm{C}$. High-pressure sodium lights were used to supplement natural light to provided a minimum $P P F$ of $100 \mu \mathrm{mol} \cdot \mathrm{m}^{-2} \cdot \mathrm{s}^{-1}$ at the plant canopy for $12 \mathrm{~h}$ per day. Plants were grown in a complete, modified Hoagland's all nitrate solution, minus $\mathrm{Ca}$ or $\mathrm{B}$, and $0.25 \times \mathrm{Ca}$ or B: (macronutrients in $\mathrm{mm}$ ) $15 \mathrm{NO}_{3}-\mathrm{N}, 1.0$ $\mathrm{PO}_{4}-\mathrm{P}, 6.0$ potassium, $5.0 \mathrm{Ca}, 2.0$ magnesium, and $2.0 \mathrm{SO}_{4}-\mathrm{S}$ (Hoagland and Arnon, 1950) plus $\mu \mathrm{M}$ concentrations of micronutrients, 72 iron, 9.0 manganese, 1.5 copper, 1.5 zinc, $45.0 \mathrm{~B}$, and 0.1 molybdenum. The following reagent-grade chemicals: $\mathrm{KNO}_{3}$, $\mathrm{Ca}\left(\mathrm{NO}_{3}\right)_{2}, \quad \mathrm{KH}_{2} \mathrm{PO}_{4}, \quad \mathrm{MgSO}_{4}, \quad \mathrm{NaNO}_{3}$, FeDTPA, $\mathrm{MnCl}_{2}, \mathrm{ZnSO}_{4}, \mathrm{CuCl}, \mathrm{H}_{3} \mathrm{BO}_{3}$, $\mathrm{Na}_{2} 2 \mathrm{MoO}_{4}$, and deionized water were used to formulate treatment solutions. When $\mathrm{Ca}$, supplied in the form of $\mathrm{CaNO}_{3}$, was removed from the solution, the nitrate was replaced with $\mathrm{NaNO}_{3}$. The plants were small and did not use large quantities of nutrient solutions; therefore, solutions were replaced every 2 weeks. At this time, the $\mathrm{pH}$ was adjusted to 5.8 using $0.1 \mathrm{M} \mathrm{NaOH}$; electrical conductivity was also measured; no difference was observed between any treatment solution (data not shown). Unlike the pansy plants that were treated with a complete, minus $\mathrm{Ca}$ or $\mathrm{B}$, and $0.25 \times \mathrm{Ca}$ or $\mathrm{B}$, petunias and gerberas were only treated with a complete, minus $\mathrm{Ca}$, or minus $\mathrm{B}$ solution. The experiment was a completely randomized design with three replications of each treatment. There were 36 tubes per replication. Plants were inspected weekly for deficiency symptoms and plant tissue was harvested $35 \mathrm{~d}$ after sowing (DAS); plants from 36 tubes (one replication) were combined to obtain a sufficient amount of dry tissue to conduct analysis. Tissue samples were taken by removing the two most recently mature leaves from the control, $0.25 \times \mathrm{B}$ and $\mathrm{Ca}$ treatments, and the entire plant, excluding the cotyledons, for the minus $\mathrm{B}$ and $\mathrm{Ca}$ treatments.

Expt. 2: Temporary disruption of calcium and boron availability. Seeds of the same cultivars were sown and grown similarly, except for fertilization, to those in Expt. 1. All plants were provided with a complete, modified Hoagland's solution except from 15 to 21 DAS (Week 3), 22 to 28 DAS (Week 4), or 29 to 35 DAS (Week 5). At those times, the complete solution was replaced with minus $\mathrm{Ca}$ or minus $\mathrm{B}$ solutions. At the beginning and end of the fertilization disruption phase, the oasis was flushed three times with the replacement solution to leach the substrate. A control treatment that received a complete solution for the entire duration of the experiment was also included. After plants had been deprived of $\mathrm{Ca}$ or $\mathrm{B}$ for $7 \mathrm{~d}$, a complete solution was reintroduced. Visual observations for deficiency symptoms were done weekly. Plants that were deprived of $\mathrm{Ca}$ during Week 3 were harvested 28 DAS as a result of the severe effects the treatment had and the decline of the plants. For the other two treatments, tissue was harvested 42 DAS after germination by removing the entire plant excluding the cotyledons. Each replication consisted of a tub holding 36 seedlings. The experiment was a completely randomized design with four replications of each treatment.

Tissue analysis. The tissue samples for both experiments were collected at termination and were first rinsed in deionized water, then washed in $0.2 \mathrm{~N} \mathrm{HCl}$ for $30 \mathrm{~s}$, rerinsed with deionized water, and dried at $70{ }^{\circ} \mathrm{C}$ for $72 \mathrm{~h}$. Dried tissue was ground in a stainless steel Wiley mill through a 1-mm screen (20mesh) and $0.15 \mathrm{~g}$ was digested in a microwave digester (MARS; CEM Corp, Matthews, NC) using a modified EPA method (EPA method 3051; Nelson, 1988; $\mathrm{HNO}_{3}$ digestion at $200{ }^{\circ} \mathrm{C}$ with an additional peroxide digestion step). Nutrient concentration, except nitrogen, was determined with inductively coupled plasma optical emission spectroscopy (ICP-OES; Model IRIS Intrepid II; Thermo Corp., Waltham, MA). The lower detection limits for B, copper, iron, and manganese were $1.70,0.55,46.00$, and
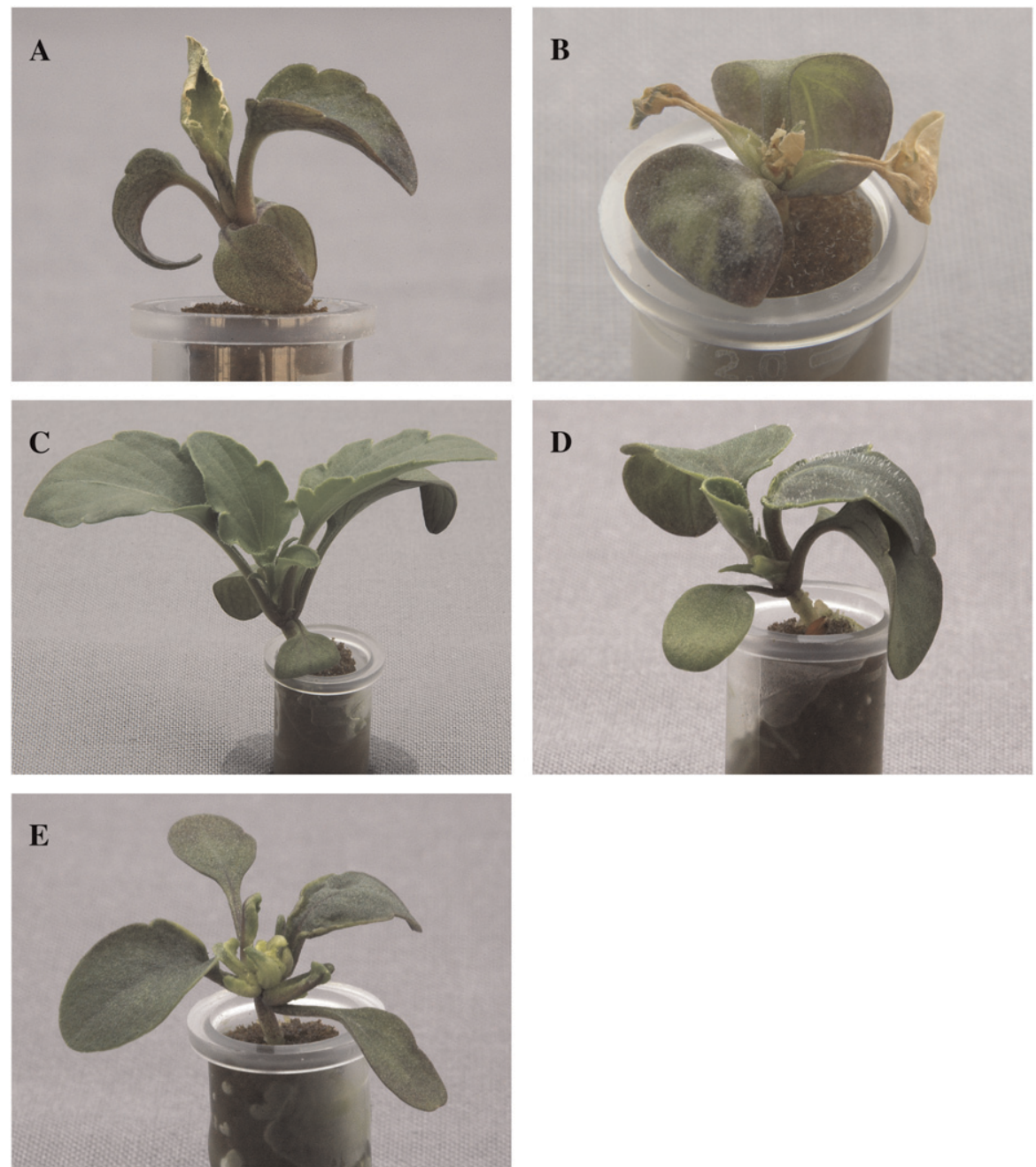

Fig. 1. 'Dynamite Yellow' pansy plants $39 \mathrm{~d}$ after sowing with initial (A) or advanced (B) calcium deficiency symptoms, control (C), initial (D), or advanced (E) boron deficiency symptoms (Expt. 1).
$16.00 \mathrm{mg} \cdot \mathrm{L}^{-1}$, respectively, and were not detectable below these limits

Data analysis. Data were tested by analysis of variance using general linear model (SAS Institute, Cary, NC) and means were separated by least significant differences at $P \leq 0.05$.

\section{Results and Discussion}

\section{Expt. 1}

Pansies minus calcium. Plants with initial Ca deficiency turned purple-brown on the petioles and leaf tips and had a upward leaf curl (Fig. 1A). Moderate symptoms included greater discoloration and more prominent upward leaf curling as well as necrosis of the leaf tips. At advanced stages of the deficiency, whole leaves and the apical meristem became necrotic (Fig. 1B). Plants receiving treatments of $0.25 \times \mathrm{Ca}$ and minus $\mathrm{Ca}$ had tissue concentrations of $0.27 \%$ and $0.03 \% \mathrm{Ca}$, respectively, which were significantly $(P \leq 0.001)$ lower than the control (Table 1). These values for plugs were below previous reported tissue concentrations for 
Table 1. 'Dynamite Yellow' pansy tissue concentrations at $35 \mathrm{~d}$ after sowing treated with a complete, $0.25 \times$ calcium $(\mathrm{Ca})$, minus $\mathrm{Ca}, 0.25 \times$ boron $(\mathrm{B})$, or minus $\mathrm{B}$ modified Hoagland's solution.

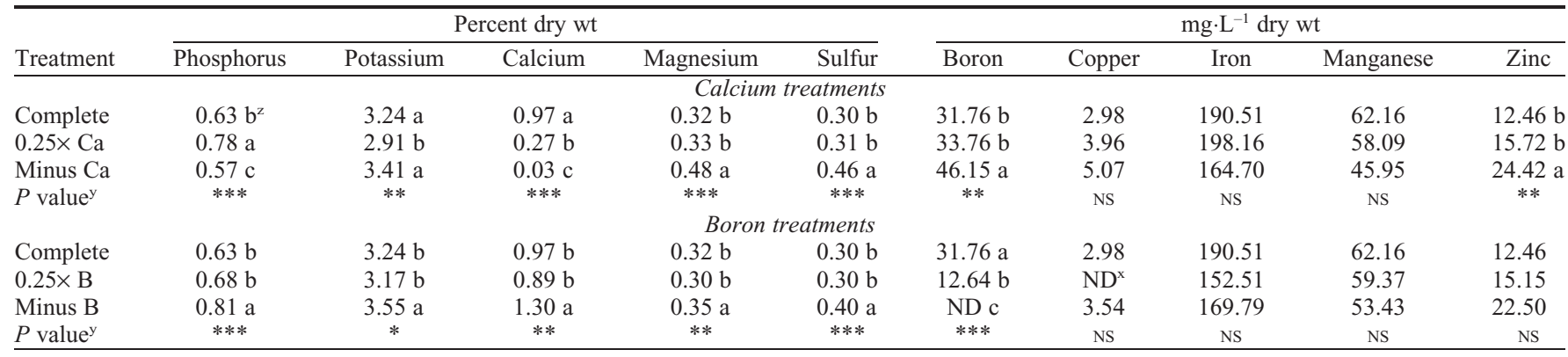

${ }^{\mathrm{z}}$ Mean separations are shown by $\mathrm{Ca}$ or $\mathrm{B}$ treatment and are in columns under each element.

$\mathrm{y}_{\mathrm{NS}}, *, * *, * * *$ Nonsignificant or significant at $P \leq 0.05, \leq 0.01$, or $\leq 0.001$.

${ }^{\mathrm{x}}$ Not detectable.

early and advanced Ca deficiency symptoms for fully expanded mature leaves from transplanted pansies (46 DAS), which were $0.45 \%$ and $0.61 \%$, respectively (Pitchay, 2002). The tissue concentration of sulfur, magnesium, B, and zinc were inversely related to the amount of $\mathrm{Ca}$ in the solution (Table 1). The lower concentration of magnesium, B, and zinc may be attributed to the known antagonistic role Ca has on those elements (Gupta, 1993b; Jones and Scarseth, 1944; Marschner, 1995; Robson and Pitman, 1983).

Pansies minus boron. Plants with initial B deficiency had leaves that exhibited upward curling (Fig. 1D). Plants with moderate B deficiency symptoms were thicker and had leaves more prominently curled upward. Advanced deficiency symptoms included thickened, smaller leaves as compared with the control and distorted meristems and young leaves (Fig. 1E). Plants receiving treatments of $0.25 \times \mathrm{B}$ had tissue concentrations of $12.64 \mathrm{mg} \cdot \mathrm{L}^{-1} \mathrm{~B}$, which was significantly $(P \leq 0.001)$ lower than the control; tissue concentrations of $\mathrm{B}$ were non-detectable (ND) for plants receiving treatment of minus B. These concentrations were to be expected because Pitchay (2002) reported symptoms appearing when tissue concentrations of $\mathrm{B}$ were between 9.7 and $10.9 \mathrm{mg} \cdot \mathrm{L}^{-1}$ for fully expanded mature leaves from transplanted pansies (72 DAS). When B was excluded from the solution, the tissue concentration of phosphorus, potassium, $\mathrm{Ca}$, sulfur, and magnesium increased (Table 1). Mishra et al. (2009) reported similar results with geranium tissue wherein lower concentrations of B led to higher concentrations of phosphorus and sulfur. However, in their study, potassium, $\mathrm{Ca}$, and magnesium decreased with decreased B concentrations.

Petunias minus calcium. Plants not receiving $\mathrm{Ca}$ were smaller than those receiving $\mathrm{Ca}$ (visual comparison). Plants exhibiting an initial deficiency were chlorotic and beginning to become necrotic (Fig. 2A). Plants with moderate $\mathrm{Ca}$ deficiency symptoms had distinct necrotic regions on the leaves, primarily on the tips. Plants that exhibited advanced $\mathrm{Ca}$ deficiency symptoms were almost completely necrotic (Fig. 2B). Tissue concentrations of $\mathrm{Ca}$ in plants treated with a nutrient solution minus $\mathrm{Ca}$ were significantly $(P \leq 0.01)$ lower than those treated with a complete nutrient solution (Table 2). These values were below previous reported tissue concentrations for early and advanced $\mathrm{Ca}$ deficiency symptoms, which were $0.32 \%$ and $0.38 \%$, respectively, for fully expanded mature leaves from transplanted petunias (88 DAS) (Pitchay, 2002).

Tissue concentrations of zinc were significantly $(P \leq 0.01)$ greater in plants treated
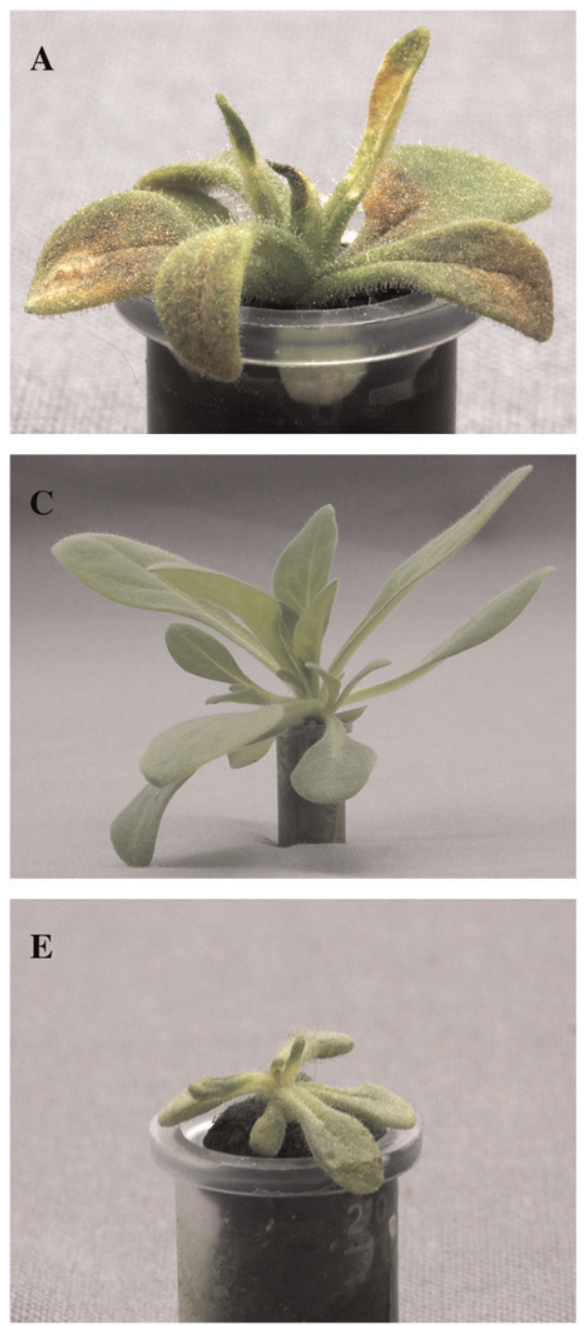

Fig. 2. 'White Storm' petunia plants $39 \mathrm{~d}$ after sowing with initial (A) or advanced (B) calcium deficiency symptoms, control (C), initial (D), or advanced (E) boron deficiency symptoms (Expt. 1).
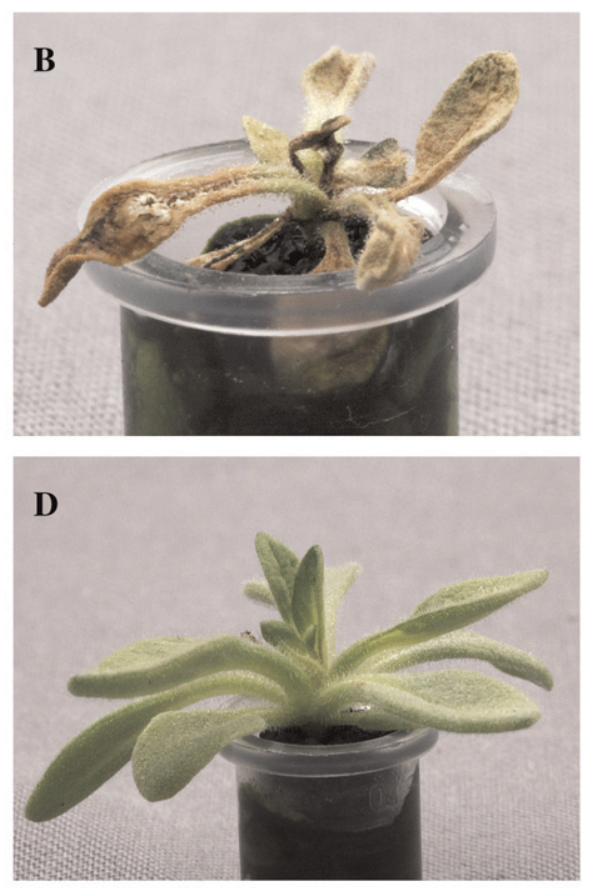

with a nutrient solution minus $\mathrm{Ca}$, which could be the result of the lack of $\mathrm{Ca}$ antagonism previously mentioned (Table 2); however, potassium values in plants treated with the minus Ca solution were significantly $(P \leq$ $0.05)$ lower than those treated with the control (Table 2).

Petunia minus boron. Plants not receiving B were smaller than those receiving B. Plants exhibiting early signs of B deficiency had 
Table 2. 'White Storm' petunia tissue concentrations at $35 \mathrm{~d}$ after sowing treated with a complete, minus calcium, or minus boron modified Hoagland's solution.

\begin{tabular}{|c|c|c|c|c|c|c|c|c|c|c|}
\hline \multirow[b]{2}{*}{ Treatment } & \multicolumn{5}{|c|}{ Percent dry wt } & \multicolumn{5}{|c|}{$\mathrm{mg} \cdot \mathrm{L}^{-1}$ dry wt } \\
\hline & Phosphorus & Potassium & Calcium & Magnesium & Sulfur & Boron & Copper & Iron & Manganese & Zinc \\
\hline Complete & 0.86 & $7.94 \mathrm{a}^{\mathrm{z}}$ & $1.54 \mathrm{a}$ & 0.41 & 0.31 & 29.70 & 7.44 & $\mathrm{ND}^{\mathrm{y}}$ & ND & $12.76 \mathrm{~b}$ \\
\hline \multicolumn{11}{|c|}{ Boron treatment } \\
\hline Complete & 0.86 & 7.94 & 1.54 & 0.41 & 0.31 & $29.70 \mathrm{a}$ & 7.44 & $\mathrm{ND}^{\mathrm{z}}$ & ND & 12.76 \\
\hline
\end{tabular}

${ }^{\mathrm{z}}$ Mean separations are shown by calcium $(\mathrm{Ca})$ or boron $(\mathrm{B})$ treatment and are in columns under each element.

y Not detectable.

${ }^{\mathrm{NS}}, *, * *, * *$ Nonsignificant or significant at $P \leq 0.05, \leq 0.01$, or $\leq 0.001$.

thickened, brittle leaves (Fig. 2D). Moderate symptoms also included distortion and straplike young leaves. Plants exhibiting advanced symptoms were the smallest in size; all leaves and the apical meristem exhibited signs of distortion (Fig. 2E). Tissue concentrations of $\mathrm{B}$ were ND in plants treated with the minus B solution and control plants had B tissue concentrations of $29.70 \mathrm{mg} \cdot \mathrm{L}^{-1}$, which is within the acceptable range reported by Pitchay (2002) for fully expanded mature leaves from transplanted petunias (102
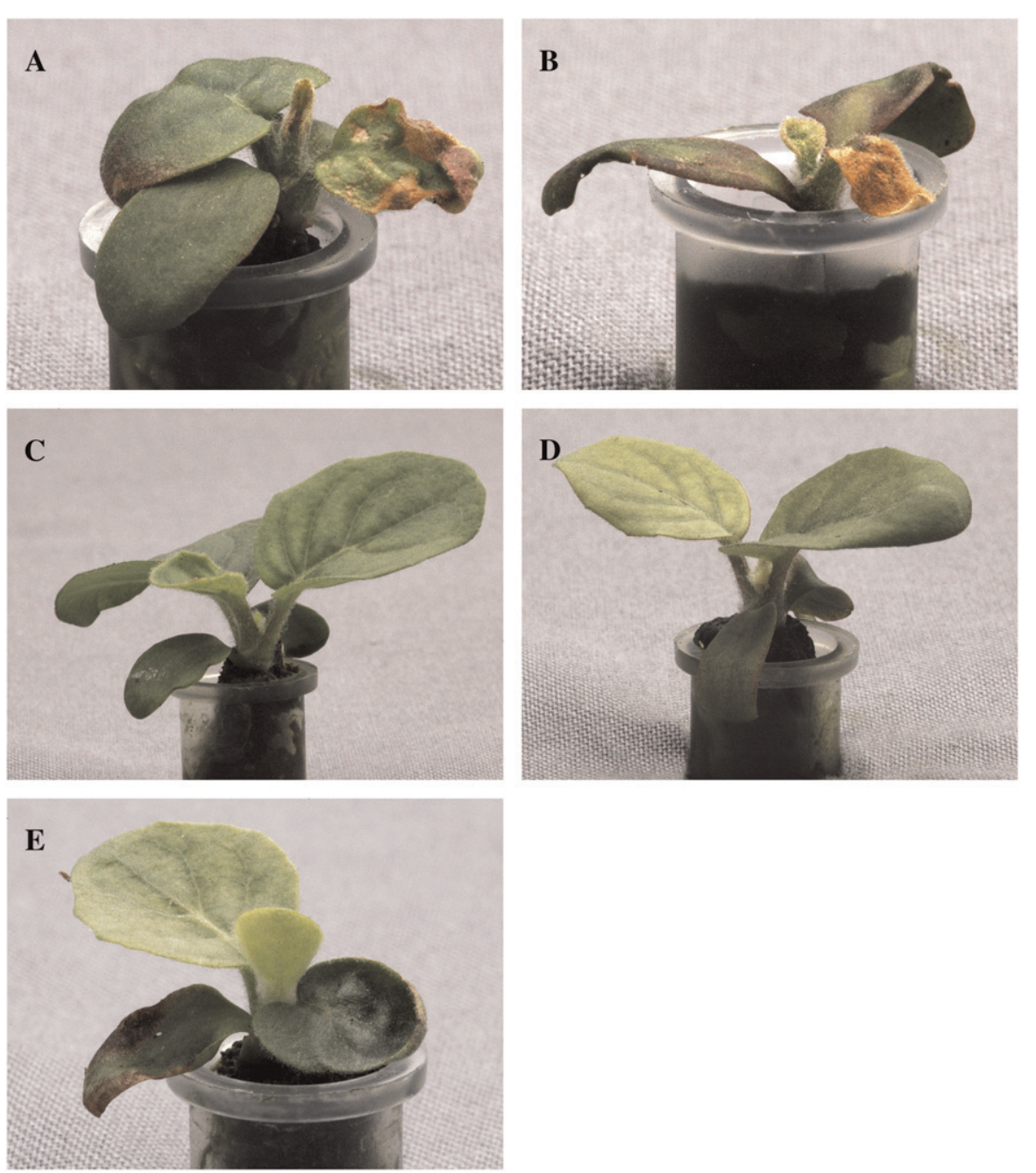

Fig. 3. 'Festival Apricot' gerbera plants $39 \mathrm{~d}$ after sowing with initial (A) or advanced (B) calcium deficiency symptoms, control (C), initial (D), or advanced (E) boron deficiency symptoms (Expt. 1).

DAS) (Table 2). Treatments had no effect on any other analyzed element.

Gerbera minus calcium. Plants exhibiting an initial deficiency had leaves that had some bronzing on the margins of older leaves and younger leaves were curled and necrotic on the edges (Fig. 3A). The bronzing color was more pronounced on plants with moderate symptoms and necrosis was more pronounced on younger leaves. Plants with advanced symptoms had fewer leaves and bronzing on older leaves and younger leaves

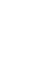


Table 3. 'Festival Apricot' gerbera tissue concentrations at $35 \mathrm{~d}$ after sowing treated with a complete minus calcium (Ca) or minus boron (B) modified Hoagland's solution.

\begin{tabular}{|c|c|c|c|c|c|c|c|c|c|c|}
\hline \multirow[b]{2}{*}{ Treatment } & \multicolumn{5}{|c|}{ Percent dry wt } & \multicolumn{5}{|c|}{$\mathrm{mg} \cdot \mathrm{L}^{-1}$ dry wt } \\
\hline & Phosphorus & Potassium & Calcium & Magnesium & $\overline{\text { Sulfur }}$ & Boron & Copper & Iron & Manganese & $\overline{\text { Zinc }}$ \\
\hline \multicolumn{11}{|c|}{ Calcium treatments } \\
\hline Complete & 0.42 & 2.88 & $1.08 \mathrm{a}^{\mathrm{z}}$ & $0.33 \mathrm{~b}$ & $0.31 \mathrm{a}$ & $37.39 \mathrm{~b}$ & 4.26 & 49.34 & $\mathrm{ND}^{\mathrm{y}}$ & 13.34 \\
\hline Minus $\mathrm{Ca}$ & 0.41 & 3.13 & $0.10 \mathrm{~b}$ & $0.40 \mathrm{a}$ & $0.25 \mathrm{~b}$ & $46.92 \mathrm{a}$ & 4.85 & ND & 25.45 & 18.76 \\
\hline$P$ value ${ }^{\mathrm{x}}$ & NS & NS & $* * *$ & $*$ & $* *$ & $*$ & NS & NS & NS & NS \\
\hline \multicolumn{11}{|c|}{ Boron treatments } \\
\hline Complete & 0.42 & 2.88 & 1.08 & 0.33 & 0.31 & $37.39 \mathrm{a}$ & 4.26 & 49.34 & $\mathrm{ND}^{\mathrm{z}}$ & 13.34 \\
\hline Minus B & 0.40 & 2.80 & 1.03 & 0.30 & 0.29 & $\mathrm{ND} b$ & 4.67 & ND & ND & 18.92 \\
\hline$P$ value ${ }^{\mathrm{x}}$ & NS & NS & NS & NS & NS & $* * *$ & NS & NS & NS & NS \\
\hline
\end{tabular}

${ }^{\mathrm{z}}$ Mean separations are shown by $\mathrm{Ca}$ or B treatment and are in columns under each element.

${ }^{\mathrm{y}}$ Not detectable.

${ }_{\mathrm{NS}}, * * *, * * *$ Nonsignificant or significant at $P \leq 0.05, \leq 0.01$, or $\leq 0.001$.

Table 4. Comparison of 'Dynamite Yellow' pansy tissue concentration of plants grown with a complete modified Hoagland's solution or distributed calcium supply. ${ }^{z}$

\begin{tabular}{|c|c|c|c|c|c|c|c|c|c|c|}
\hline \multirow[b]{2}{*}{ Treatment } & \multicolumn{5}{|c|}{ Percent dry wt } & \multicolumn{5}{|c|}{$\mathrm{mg} \cdot \mathrm{L}^{-1}$ dry wt } \\
\hline & Phosphorus & Potassium & Calcium & Magnesium & $\overline{\text { Sulfur }}$ & Boron & Copper & Iron & Manganese & Zinc \\
\hline Week 3 & 0.40 & $3.73 \mathrm{a}$ & $0.56 \mathrm{~b}$ & $0.44 \mathrm{a}$ & $0.51 \mathrm{a}$ & 47.98 & $8.50 \mathrm{a}$ & $179.13 \mathrm{a}$ & $41.15 \mathrm{a}$ & $25.50 \mathrm{a}$ \\
\hline Complete & 0.50 & 3.92 & $1.18 \mathrm{a}$ & 0.46 & 0.47 & 78.88 & 7.75 & 157.90 & $\mathrm{ND}^{\mathrm{w}}$ & 11.20 \\
\hline Week 4 & 0.48 & 3.46 & $0.83 \mathrm{~b}$ & 0.39 & 0.42 & 70.13 & 6.45 & 144.28 & ND & 7.40 \\
\hline Week 5 & 0.57 & 3.77 & $0.81 \mathrm{~b}$ & 0.39 & 0.46 & 70.78 & 6.65 & 157.53 & ND & 5.75 \\
\hline
\end{tabular}

${ }^{z}$ Tissue concentrations at $28 \mathrm{~d}$ after sowing (DAS) treated with a complete modified Hoagland's solution and calcium (Ca) supply disrupted from d 15 to d 21 (Week 3) after sowing; and tissue concentrations for pansy plants at $42 \mathrm{~d}$ of age treated with a complete modified Hoagland's solution and Ca supply disrupted from 15 to 21 DAS (Week 3), 22 to 28 DAS (Week 4), or 29 to 35 DAS (Week 5).

${ }^{\mathrm{y}}$ Mean separations are shown by treatment and are in columns under each element.

${ }^{\mathrm{N} S}, *, * * *$ Nonsignificant or significant at $P \leq 0.05$ or $\leq 0.001$.

wNot detectable.

that reported by Pitchay (2002) in which 4week-old pansies began discoloring $8 \mathrm{~d}$ after Ca-deficient conditions were introduced and necrosis appeared $9 \mathrm{~d}$ after treatment initiation. Concentrations of $\mathrm{Ca}$ in plant tissue of plants deprived of $\mathrm{Ca}$ during Week 4 or 5 were $0.83 \%$ and $0.81 \%$, respectively, and were significantly $(P \leq 0.05)$ lower than the concentration of the controls $(1.18 \%)$ (Table 4).

Pansies minus boron. At the time of termination, plants deprived of $\mathrm{B}$ during Week 3, 4, or 5 displayed visual symptoms of $\mathrm{B}$ deficiency. There was no difference in $\mathrm{B}$ concentration between the control plants and plants deprived of B during Week 3. Plants deprived of B during Week 4 or 5 had B tissue concentrations of 67.80 and $66.08 \mathrm{mg} \cdot \mathrm{L}^{-1}$, respectively, which were significantly $(P$ $\leq 0.05)$ lower than the control $\left(78.88 \mathrm{mg} \cdot \mathrm{L}^{-1}\right)$ (Table 5). Concentrations of phosphorus for plants deprived of B in Week 4 were significantly $(P \leq 0.05)$ higher than the controls (Table 5); however, all values were within an acceptable range for fully expanded mature leaves from transplanted pansies (72 DAS) (Pitchay, 2002).

Petunias minus calcium. There was no difference in Ca concentration between the control and plants deprived of Ca during Week 3 . Plants that did not receive Ca during Week 4 or $5 \mathrm{had} \mathrm{Ca}$ tissue concentrations of $1.50 \%$ and $1.44 \%$, respectively, which were significantly $(P \leq 0.001)$ lower than the concen- tration of the controls $(2.09 \%)$ (Table 6). Although lower than the controls, Ca values for plants not receiving Ca during Week 4 or 5 were within the recommended range (Pitchay, 2002). Despite the sufficient Ca tissue values, plants in all treatments deprived of $\mathrm{Ca}$ displayed $\mathrm{Ca}$ deficiency symptoms. The tissue concentration of magnesium was inversely related to the amount of $\mathrm{Ca}$ in the solution (Table 6). As previously mentioned, lower concentrations of magnesium may be attributed to the antagonistic effect from Ca (Gupta, 1993b; Jones and Scarseth, 1944; Marschner, 1995; Robson and Pitman, 1983).

Petunias minus boron. There were no measurable differences in B tissue concentration among any of the treatments; however, symptoms were visible in all treatments deprived of B. In fact, the only treatment in which B level was detectable was in the control, but even control plants were well below the level in which deficiency symptoms would be expected. Analyzing petunias for B has created problems in the past and a suitable detection method using the ICP-OES for $\mathrm{B}$ in petunias has not been developed (J. Frantz, personal observation). No matter when B was deprived, both phosphorus and sulfur concentrations were significantly ( $P \leq$ $0.05)$ lower than the concentration of the controls (Table 6).

Gerbera minus calcium. Plants deprived of $\mathrm{Ca}$ during any interval displayed $\mathrm{Ca}$ deficiency symptoms but had tissue concentrations within the sufficiency range reported by Jones et al. (1991) and did not have significantly $(P \leq 0.05)$ different tissue concentrations of $\mathrm{Ca}$ than the control (Table 7). Plants deprived of Ca during Week 4 or 5 had significantly higher concentrations of magnesium than the control (Table 7). The tissue concentration of $\mathrm{B}$ was inversely related to the amount of $\mathrm{Ca}$ in the solution (Table 7).

Gerbera minus boron. Plants deprived of $\mathrm{B}$ at any interval did not have significantly $(P \leq 0.05)$ different tissue concentrations of $B$ than the control (Table 7); however, deficiency symptoms appeared. This is consistent with tissue tests done on plants in greenhouse production; by the time tissue samples were taken in this experiment and by growers, B could have been taken up by the plant, masking the deficiency (unpublished data). The concentrations of $B$ in all treatments were within the published sufficiency range (Jones et al., 1991). There were significant $(P \leq 0.05)$ differences in the concentrations of $\mathrm{S}$ among treatments; these concentrations were inversely related to the amount of B in the solution (Table 7).

Regardless of when the pansy, petunia, or gerbera plants were deprived of $\mathrm{Ca}$ or $\mathrm{B}$, the visual symptoms of the respective deficiency were present. Symptoms for $\mathrm{Ca}$ deficiency included chlorosis along leaf margins, upward curling of leaves, and necrosis, although symptoms for B deficiency included leaf 
Table 5. 'Dynamite Yellow' pansy tissue concentrations at $42 \mathrm{~d}$ after sowing (DAS) treated with a complete modified Hoagland's solution and boron supply disrupted from 15 to 21 DAS (Week 3), 22 to 28 DAS (Week 4), or 29 to 35 DAS (Week 5).

\begin{tabular}{|c|c|c|c|c|c|c|c|c|c|c|}
\hline \multirow[b]{2}{*}{ Treatment } & \multicolumn{5}{|c|}{ Percent dry wt } & \multicolumn{5}{|c|}{$\mathrm{mg} \cdot \mathrm{L}^{-1}$ dry wt } \\
\hline & Phosphorus & Potassium & Calcium & Magnesium & Sulfur & Boron & Copper & Iron & Manganese & Zinc \\
\hline Complete & $0.50 \mathrm{~b}^{\mathrm{z}}$ & 3.92 & 1.18 & 0.46 & 0.47 & $78.88 \mathrm{a}$ & 7.75 & 157.90 & $\mathrm{ND}^{\mathrm{y}}$ & 11.20 \\
\hline Week 3 & $0.57 \mathrm{ab}$ & 4.11 & 1.02 & 0.42 & 0.40 & $77.50 \mathrm{a}$ & 5.58 & 98.98 & ND & 27.50 \\
\hline Week 4 & $0.63 \mathrm{a}$ & 4.03 & 1.16 & 0.45 & 0.43 & $67.80 \mathrm{~b}$ & 4.95 & 118.18 & ND & 8.00 \\
\hline Week 5 & $0.58 \mathrm{ab}$ & 4.10 & 1.22 & 0.46 & 0.46 & $66.08 \mathrm{~b}$ & 6.55 & 160.63 & ND & 28.10 \\
\hline$P$ value ${ }^{\mathrm{x}}$ & $*$ & NS & NS & NS & NS & $*$ & NS & NS & NS & NS \\
\hline
\end{tabular}

${ }^{\mathrm{z}}$ Mean separations are shown by treatment and are in columns under each element.

'Not detectable.

${ }_{\mathrm{NS}}$, *Nonsignificant or significant at $P \leq 0.05$.

Table 6. 'White Storm' petunia tissue concentrations at $42 \mathrm{~d}$ after sowing (DAS) treated with a complete modified Hoagland's solution and calcium or boron supply disrupted from 15 to 21 DAS (Week 3), 22 to 28 DAS (Week 4), or 29 to 35 DAS (Week 5).

\begin{tabular}{|c|c|c|c|c|c|c|c|c|c|c|}
\hline \multirow[b]{2}{*}{ Treatment } & \multicolumn{5}{|c|}{ Percent dry wt } & \multicolumn{5}{|c|}{$\mathrm{mg} \cdot \mathrm{L}^{-1}$ dry wt } \\
\hline & Phosphorus & Potassium & Calcium & Magnesium & $\overline{\text { Sulfur }}$ & Boron & Copper & Iron & Manganese & Zinc \\
\hline Complete & 0.98 & $6.28 \mathrm{ab}^{\mathrm{z}}$ & $2.09 \mathrm{a}$ & $0.54 \mathrm{~b}$ & $0.33 \mathrm{ab}$ & $\mathrm{ND}^{\mathrm{y}}$ & 4.22 & 69.77 & 22.40 & 75.14 \\
\hline Week 3 & 1.13 & $6.82 \mathrm{a}$ & $2.14 \mathrm{a}$ & $0.62 \mathrm{a}$ & $0.37 \mathrm{a}$ & ND & 4.77 & 85.75 & 23.63 & 25.63 \\
\hline Week 5 & 0.80 & $5.56 \mathrm{bc}$ & $1.44 \mathrm{~b}$ & $0.63 \mathrm{a}$ & $0.29 \mathrm{~b}$ & ND & 4.32 & 57.16 & 25.60 & 14.83 \\
\hline$P$ value $^{\mathrm{x}}$ & NS & $* *$ & $* * *$ & * & $* *$ & NS & NS & NS & NS & NS \\
\hline \multicolumn{11}{|c|}{ Boron treatments } \\
\hline Week 4 & $0.78 \mathrm{~b}$ & 6.24 & 2.08 & 0.54 & $0.33 \mathrm{~b}$ & ND & 4.04 & 57.08 & 20.98 & 8.37 \\
\hline Week 5 & $0.74 \mathrm{~b}$ & 6.11 & 2.13 & 0.56 & $0.33 \mathrm{~b}$ & ND & 4.39 & 49.79 & 25.03 & 7.91 \\
\hline$P$ value ${ }^{\mathrm{x}}$ & * & NS & NS & NS & * & NS & NS & NS & NS & NS \\
\hline
\end{tabular}

${ }^{\mathrm{z}}$ Mean separations are shown by calcium or boron treatment and are in columns under each element.

${ }^{y}$ Not detectable.

${ }_{\mathrm{NS}}, *, * * * *$ Nonsignificant or significant at $P \leq 0.05, \leq 0.01$, or $\leq 0.001$.

Table 7. 'Festival Apricot' gerbera tissue concentrations at $42 \mathrm{~d}$ after sowing (DAS) treated with a complete modified Hoagland's solution and calcium or boron supply disrupted from 15 to 21 DAS (Week 3), 22 to 28 DAS (Week 4), or 29 to 35 DAS (Week 5).

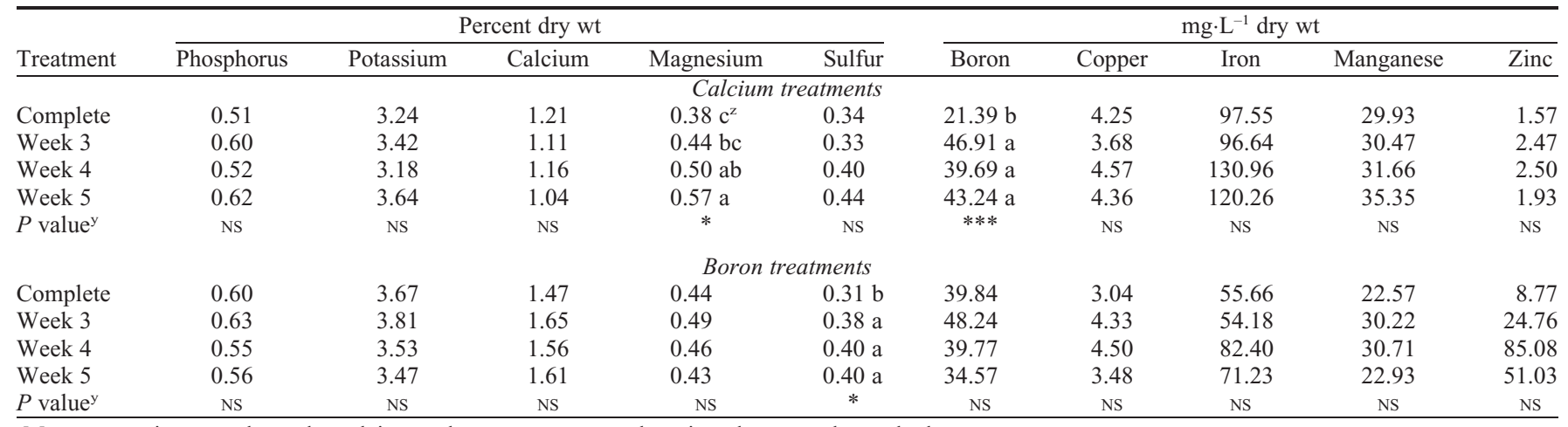

${ }^{\mathrm{z}}$ Mean separations are shown by calcium or boron treatment and are in columns under each element.

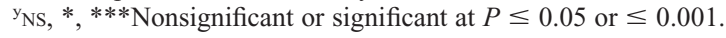

curling, distorted apical meristems, and proliferation of auxiliary shoots. Like in Expt. 1, plants deprived of $\mathrm{Ca}$ exhibited necrosis and plants deprived of $\mathrm{B}$ had no necrosis. The plants did not recover from the visual symptoms even when $\mathrm{Ca}$ or $\mathrm{B}$ was reintroduced in the nutrient solutions, although at times, tissue $\mathrm{Ca}$ and $\mathrm{B}$ concentrations returned to sufficiency levels and were not different from the control.

\section{Conclusion}

The results from Expt. 1 demonstrated the clear differences between symptoms caused by $\mathrm{Ca}$ and $\mathrm{B}$ deficiencies. Pansy, petunia, and gerbera plants experiencing $\mathrm{Ca}$ deficiency were generally smaller than control plants, exhibited discoloration, and ultimately necrosis. Plants that experienced B deficiency typically had distorted growth of the newest tissue and rarely had any necrosis present.

The tissue concentrations of $\mathrm{Ca}$ and $\mathrm{B}$ in the three species in Expt. 2 were often within the recommended sufficiency range for $\mathrm{Ca}$ or $\mathrm{B}$ even when the respective element had been temporarily excluded. However, the plants still exhibited visual symptoms of being deficient in either $\mathrm{Ca}$ or $\mathrm{B}$. Because tissue was analyzed after the period when the nutrients were resupplied to the plants, it is likely that subsequent $\mathrm{Ca}$ or B uptake masked lower nutrient concentrations present during the periods of deprivation. Mishra et al. (2009) report that geranium root swelling was observed within $1 \mathrm{~d}$ of withdrawing B from the nutrient solution. The observation of deficiency symptoms $1 \mathrm{~d}$ after B deprivation supports our findings of symptoms persisting after a complete nutrient solution was reintroduced. Sampling for tissue concentrations of $\mathrm{B}$ and $\mathrm{Ca}$ once symptoms are visible may cause misdiagnosis. Routine sampling may be necessary to detect low levels of $\mathrm{B}$ and $\mathrm{Ca}$ before symptoms are visible.

In these two studies, we have shown that the symptoms that have been observed in 
plug production greenhouses were most similar to those symptoms caused by B deficiency. Also, a temporary disruption of either $\mathrm{Ca}$ or B can cause lasting symptoms throughout the plug production cycle.

\section{Literature Cited}

Clarkson, D.T. 1984. Calcium transport between tissues and its distribution in the plant. Plant Cell Environ. 7:449-456.

Gupta, U.C. 1993a. Deficiency and toxicity symptoms of boron in plants, p. 147-155. In: Gupta, U.C. (ed.). Boron and its role in crop production. CRC Press, Ann Arbor, MI.

Gupta, U.C. 1993b. Factors affecting boron uptake by plants, p. 87-104. In: Gupta, U.C. (ed.). Boron and its role in crop production. CRC Press, Ann Arbor, MI.

Hoagland, R.J. and D.I. Arnon. 1950. The waterculture method for growing plants without soil. California Agr. Exp. Sta.

Jiao, X.Y., Y.G. Zhu, B.C. Jarvis, W.P. Quick, and P. Christie. 2005. Effects of boron on leaf expansion and intercellular airspaces in mung bean in solution culture. J. Plant Nutr. 28:351361.

Jones, H.E. and G.D. Scarseth. 1944. The calciumboron balance in plants as related to boron needs. Soil Sci. 57:15-24.

Jones, J.B., B. Wolf, and H.A. Mills. 1991. Plant analysis handbook, Micro-Macro Publishing, Inc., Athens, GA.
Jones, J.B.J. 1991. Plant tissue analysis in micronutrients, p. 477-521. In: Mortvedt, J.J. (ed.). Micronutrients in agriculture. Soil Sci. Soc. of Amer., Inc., Madison, WI.

Kluge, R. 1971. Contribution to the problem of drought-induced $\mathrm{B}$ deficiency in agricultural crops. Arch. Acker-Pflanzenbau Bodenkd. 15: 749-754.

Kochian, L.V. 1991. Mechanisms of micronutrient uptake and translocation in plants, $\mathrm{p}$. 229-296. In: Mortvedt, J.J. (ed.). Micronutrients in agriculture. Soil Sci. Soc. of Amer., Inc., Madison, WI.

Kohl, H.C. and J.J. Oertli. 1961. Distribution of boron in leaves. Plant Physiol. 36:420-424.

Laffe, S.R. and R.C. Styer. 1989. Too B or not to B. Grower Talks 53:66.

Marschner, H. 1995. Mineral nutrition of higher plants. Academic Press, London, UK.

Matoh, T. 1997. Boron in plant cell walls. Plant Soil 193:59-70.

Mengel, K. and E.A. Kirkby. 1987. Principles of plant nutrition. Intl. Potash Inst., WorblaufenBern, Switzerland.

Mishra, S., S. Heckathorn, J. Frantz, F. Yu, and J. Gray. 2009. Effect of boron stress on geranium grown under different non-photoinhibitory light levels. J. Amer. Soc. Hort. Sci. 134:183-193.

Nelson, M.R. 1988. Index to EPA methods. EPA Circ. 901/3-88-01. U.S. Environmental Protection Agency, Washington, DC.

Nelson, P.V. 2003. Greenhouse operation and management. Prentice Hall, Upper Saddle River, NJ.
Pilbeam, D.J. and P.S. Morely. 2007. Calcium, p. 121-144. In: Barker, A.V. and D.J. Pilbeam (eds.). Handbook of plant nutrition, CRC Press, New York, NY.

Pitchay, D.S. 2002. Impact of 11 elemental nutrient deficiencies on shoot and root growth, and foliar analysis standards of 13 ornamental taxa with emphasis on $\mathrm{Ca}$ and $\mathrm{B}$ control of root apical meristem development, N.C. State Univ., Raleigh, PhD Diss. etd-09162002154007.

Raven, J.A. 1980. Short-and long-distance transport of boric acid in plants. New Phytol. 80:231-249.

Robson, A.D. and M.G. Pitman. 1983. Interactions between nutrients in higher plants, p. 147-180. In: Läuchli, A. and R.L. Bieleski (eds.). Inorganic plant nutrition. Springer-Verlag, New York, NY.

Römheld, V. and H. Marschner. 1991. Function of micronutrients in plants, p. 297-328. In: Mortvedt, J.J. (ed.). Micronutrients in agriculture, Soil Sci. Soc. of Amer., Inc., Madison, WI.

Stuart, J. 1991. Cultural practices are the primary reason for boron deficiency. Under Cover, Univ. of Mo., Columbia.

Taiz, L. and E. Zeiger. 2002. Plant Physiology. Sinauer Associates, Inc., Sunderland, MA.

Thellier, M., Y. Duval, and M. Demarty. 1979. Borate exchanges of Lemna minor L. as studied with the help of the enriched stable isotopes and of a $(n, \alpha)$ nuclear reaction. Plant Physiol. 63:283-288. 